\title{
The Anti-Cancer Effect of Watercress (Rorripa Nasturtium Aquaticum) Extract on Breast Cancer Cells
}

\author{
Neda Fallah, ${ }^{1, *}$ and Soheila Ebrahimi ${ }^{1}$ \\ ${ }^{1}$ Department of Biology, Faculty of Sciences, Payame Noor University, Babol, IR Iran \\ "Corresponding author: Neda Fallah, Department of Biology, Faculty of Sciences, Payame Noor University, Babol, IR Iran. E-mail: neda_fallah@yahoo.com
}

Received 2015 June 06; Revised 2015 August 04; Accepted 2016 August 07.

\begin{abstract}
Background: Breast cancer is the second leading cause of cancer death in women. The natural chemopreventive agent phenyl ethyl isothiocyanate (PEI) has been shown to inhibit cell growth in cancer cells. This natural antioxidant compound is derived primarily from watercress (Rorripa Nasturtium Aquaticum).

Objectives: The objective of this original paper is to study the inhibitory effects of different concentrations of watercress hydroalcoholic extract on growth inhibition of breast cancer and normal cells.

Methods: In this experimental study, Watercress (Rorripa Nasturtium Aquaticum) plant were collected from Nour, Mazandaran, Iran and dried. Then the hydroalcoholic extract were obtained from dried specimen. MDA-MB-231 breast cancer cells have been treated with different concentrations of watercress extract $(0-2 \mathrm{mg} / \mathrm{mL})$ and after 24,48 , and 72 hours of incubation, cell viability test was performed through MTT Assay to investigate the inhibitory effect of watercress extract on cancer cells. The same test has been performed on Fibroblasts cells (HF2FF cell line) to investigate the effect of this extract on normal cells. Statistical analysis was performed using one-way analysis of variance (ANOVA method) followed by post hoc Tukey's multiple comparisons test in SPSS 16 software.

Results: The mean values of MDA-MB-231 cells viability treated with different concentrations of watercress extract have meaningful differences and the mean value of cell viability has been decreased meaningfully $(\mathrm{P}<0.05)$ when the extract concentration is increased. The same analysis on Fibroblast cells represented that the mean values of cell viability in different groups don't have a meaningful difference $(\mathrm{P}<0.05)$.

Conclusions: It is concluded that watercress (Rorripa Nasturtium Aquaticum) suppressed development of human MDA-MB-231 breast cancer cells in a concentration dependent manner and it had not any meaningful impact on normal cells.
\end{abstract}

Keywords: Watercress Hydroalcoholic Extract, Breast Cancer, Isothiocyanate, Rorripa Nasturtium Aquaticum

\section{Background}

According to the recent researches of American cancer society, breast cancer is the most common cancer among American women after skin cancer and it is the second leading cause of cancer death in women, exceeded only by lung cancer. About 1 in 8 (12\%) women in the US will develop invasive breast cancer during their lifetime [1]. In recent years, breast cancer has been increased in Iran and is now ranked as the first among cancers diagnosed in women [2]. According to the latest statistics announced by the health ministry of Iran, 27 people per hundred thousand women are diagnosed with breast cancer. So, breast cancer has an enormous impact on the health of women and remains a major public health concern across the world and also in Iran [3].

Chemotherapy and Radiotherapy are two popular treatment methods for breast cancer. But, these methods are costly and they have some destructive side effects on human body [4-7]. Therefore, requirement for an efficient, low cost, and less dangerous method is sensed. Plants have been used as medicines during centuries and they were safe and low cost alternatives as medications.

\subsection{Watercress (Rorripa Nasturtium Aquaticum)}

Watercress usually thrives near spring waters, rooted in gravel washed over by clear running water. Watercress is classified in Plantae kingdom, Magnoliophyta phylum, Magnoliopsida class, Capparales order, and Cruciferae family. This plant's preference for slightly alkaline conditions made the southern England ideal for its cultivation, but today it is cultivated all around the world. Watercress has been eaten for several thousand years and multiple remedial applications are assigned to it during centuries. It has been suggested as an anti-baldness measure by Romans and Anglo-Saxons, as a pure food for ascetic hermits in Ireland, and as a mental stimulant helping decision making 
in ancient Iran and the Persian king Xerxes made his troops eat it $[8,9]$. Figure 1 represents the watercress plant.

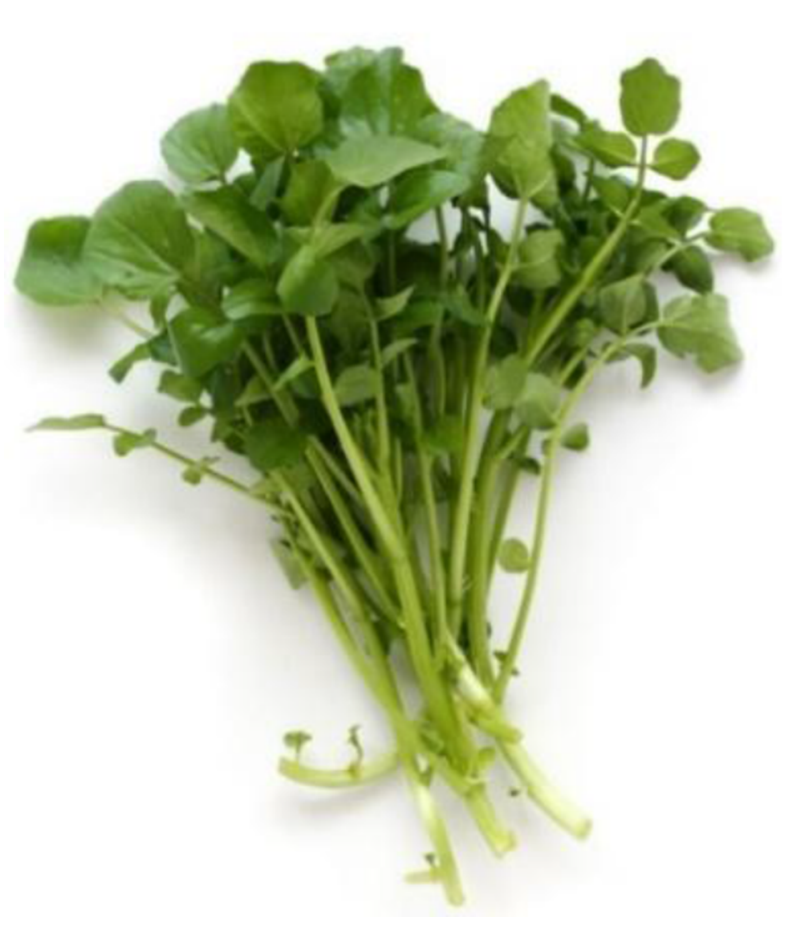

Figure 1. Watercress (Rorripa Nasturtium Aquaticum) plant

Watercress is low in fat and calories (70 mg and $11 \mathrm{kcal}$ per $100 \mathrm{~g}$ of raw plant, respectively) while it is a rich source of protein, minerals (e.g. Calcium, Potassium, Phosphorus, Sodium, Magnesium, Iron, and Zinc), and vitamins (e.g. Vitamin A, Vitamin K, Vitamin C, Vitamin B, Vitamin E, Thiamin, Niacin, and Riboflavin) [10].

Watercress is the richest source of the natural antioxidant compound, Phenyl Ethyl Isothiocyanate (PEI), being able to stop the function of a protein called Hypoxia Inducible Factor (HIF) playing a vital role in cancer development [11]. Cancer cells develop if they obtain enough oxygen and nutrients to maintain the growth. Since tumors develop rapidly, they run out of their existing blood supply. Hence, they try to send out signals to the surrounding normal tissues to grow new blood vessels into the tumor to supply oxygen and nutrients required by cancer cells. This work is done by HIF protein which has an important role in angiogenesis in tumors. It has been shown in laboratory that PEI turns off the HIF by changing the function of a second protein called 4EBP and prevent from cancer development $[12,13]$.

It is also denoted that PEI of watercress can prevent from cell growth through increasing Cisplatin which is one of the most important anticancer drugs used in the treatment of human tumors [14]. Furthermore, it is concluded that the PEI existing in watercress extract increases apoptosis as a result of inhibiting cyclooxygenase and angiogenesis in cancer cells. In fact, cyclooxygenase inhibitors decrease angiogenesis for cancer cells and consequently, prevent from cancer development [15]. The capability of PEI in metalloproteinase-9 (MMP-9) activity inhibition which leads to stop the invasion potential of cancer cells in in-vitro environment has been investigated [16]

\section{Objectives}

The main objective of this paper is to investigate the effect of different designated concentrations of watercress hydroalcoholic extract ( $0-2 \mathrm{mg} / \mathrm{mL}$ ) on breast cancer and normal cell lines through cell viability test (MTT assay).

\section{Methods}

Materials which have been used in this experimental study along with scientific methods employed to achieve the results, are described in the following sections.

\subsection{Watercress Extract}

Watercress (Rorripa Nasturtium Aquaticum) plant materials have been collected over a two-month period (November - December 2014) from countryside of Nour, Mazandaran, Iran. The specimens were washed with distilled water and then dried naturally in a dry and dark place with room temperature for about one month. The shadowdried samples were then pulverized, and $30 \mathrm{~g}$ of the ground plant material was subjected to hydroalcoholic extraction with $150 \mathrm{~mL}$ of $70 \%$ ethanol and $150 \mathrm{~mL}$ of water by using Soxhalet apparatus (Duran, A.K. 250, Germany) to obtain a solid viscous dark green mass in Plant Biology Lab of Payame Noor University (PNU) of Babol, Mazandaran, Iran. The obtained extract was then passed through the filter paper (Whatman, Germany) three times to detach the solid particles. Finally a 0.2 nanometer filter is used to sterilize the extract. Seven different concentrations of the watercress hydroalcoholic extract $(0.03125-2 \mathrm{mg} / \mathrm{mL})$ have been created.

\subsection{Cell Culture}

The human breast cancer cells (MDA-MB-231 cell line) and Fibroblast cells of human skin (HF2FF cell line) were purchased from Pasteur Institute of Iran, Tehran, Iran. MDA-MB-231 cells were cultured at $37^{\circ} \mathrm{C}, 5 \% \mathrm{CO}_{2}$ in Roswell Park Memorial Institute (RPMI 1640) medium (ATOCEL, Australia) supplemented with 10\% FBS(Fetal Bovine Serum, ATOCEL, Australia) and 1\% penicillin and streptomycin. 
HF2FF cells were cultured in Dulbecco's Modified Eagle's Medium (DMEM, ATOCEL, Australia) including 10\% FBS and $1 \%$ antibiotics (penicillin and streptomycin).

\subsection{Chemicals}

MTT (3, (4, 5-dimethylthiazol-2-yl) 2, 5-diphenyltetrazolium bromide) was purchased from Sigma, Germany. The MTT which used for MDA-MB-231 cells, was dissolved at a concentration of $5 \mathrm{mg} / \mathrm{mL}$ in RPMI 1640 (and DMEM for Fibroblast cells) at room temperature and the solution was further sterilized by filtration and stored at $4^{\circ} \mathrm{C}$ in a dark bottle equipped with a tight cap. It was prepared freshly each month.

\subsection{Cell Viability Test}

Cell Viability test was performed as previously described in [ ]. In brief, MDA-MB-231 and HF2FF cells were seeded at a density of and cells/well in a 96-well plate. MDAMB-231 cells have been divided into eight and seven groups, respectively. MDA-MB-231 and HF2FF cells were treated with $0-2 \mathrm{mg} / \mathrm{mL}$ and $0-1 \mathrm{mg} / \mathrm{mL}$ concentrations of watercress hydroalcoholic extract, respectively. The groups with 0 $\mathrm{mg} / \mathrm{mL}$ are control groups (one group for each cell line) were not treated with watercress extract. After 24,48 , and 72 hours of incubation, the cell viability was determined. 50 and $200 \mu \mathrm{L}$ (for MDA-MB-231 and HF2FF cells, respectively) of the $5 \mathrm{mg} / \mathrm{ml}$ stock solution of MTT were added to each well, and after $3 \mathrm{~h}$ of incubation at $37^{\circ} \mathrm{C}, 100$ and $700 \mu \mathrm{L}$ (for MDA-MB-231 and HF2FF cells, respectively) of the extraction buffer (Isopropanoic Acid) were added and the optical densities at $570 \mathrm{~nm}$ wavelength and $37^{\circ} \mathrm{C}$, were measured using a 96-well Elisa Reader (Biotek, ELx800, Germany), employing the extraction buffer as the blank. The quantity of Formazan (directly proportional to the number of viable cells) is measured by recording changes in optical absorbance. When cells die, they lose the ability to convert MTT into Formazan, thus color formation serves as a useful and convenient marker of only the viable cells [17].

\subsection{Statistical Analysis}

The results of cell viability test were expressed as mean standard error of mean ( \pm SEM). All data were done with the statistical package for social sciences (SPSS 16 for Windows). The results were analyzed using the one-way analysis of variance (ANOVA method) followed by post hoc Tukey's multiple comparisons test for comparing different treatment groups. Statistical significance was set at $\mathrm{P}<$ 0.05 . The results of the statistical analysis along with corresponding graphs will be represented in the following section.

\section{Results}

\subsection{Breast Cancer Cells}

According to the ANOVA test, the mean values of cell viability in MDA-MB-231 cells treated with different concentrations of watercress extract have meaningful differences. It is observed that the mean value of cell viability has been decreased meaningfully $(\mathrm{P}<0.05)$ when the extract concentration was increased. Furthermore, it is observed that the cell viability in 48 and 72 hours after treatment has been decreased with respect to 24 and 48 hours, respectively. The least cell viability has been obtained at highest concentrations of watercress extract (i.e. $2 \mathrm{mg} / \mathrm{mL}$ ) after 72 hours of incubation. Figures 2 and 3 illustrate the mean cell viability of MDA-MB-231 cells with respect to different concentrations of extract and hours after treatment, respectively. Figure 4 depicts the MDA-MB-231 cells under the microscope after 72 hours of incubation.

\subsection{Fibroblast Cells}

ANOVA test is also performed on results of MTT assay on Fibroblast cells (HF2FF cell line) and it is observed that the mean values of cell viability in cells treated with different concentrations of watercress hydroalcoholic extract, don't have a meaningful difference $(\mathrm{P}<0.05)$. It is perceived that the cell viability in 48 and 72 hours of incubation have been increased meaningfully with respect to 24 and 48 hours, respectively. Figures 5 and 6 illustrate these results, graphically. Figure 7 depicts the HF2FF cells under the microscope after 72 hours of incubation.

\section{Discussion}

This study investigated the impact of different concentration of watercress (Rorripa Nasturtium Aquaticum) hydroalcoholic extract on MDA-MB-231 (breast cancer) and HF2FF (Fibroblast) cell lines at 24, 48, and 72 hours after treatment. The results of cell viability test through MTT assay demonstrate that hydroalcoholic extract of watercress (Rorripa Nasturtium Aquaticum) suppressed the growth of human MDA-MB-231 breast cancer cells in a concentration dependent manner. It is observed that watercress extract had not any meaningful impact on normal cells viability.

According to the increasing risk of breast cancer entire the world, various methods such as chemotherapy, hormone-therapy, radiotherapy, and surgery have been proposed which may lead some unpleasant effects. For example, chemotherapy yields to blood cells decrease and hair loss, hormone-therapy may lead to blood coagulation 


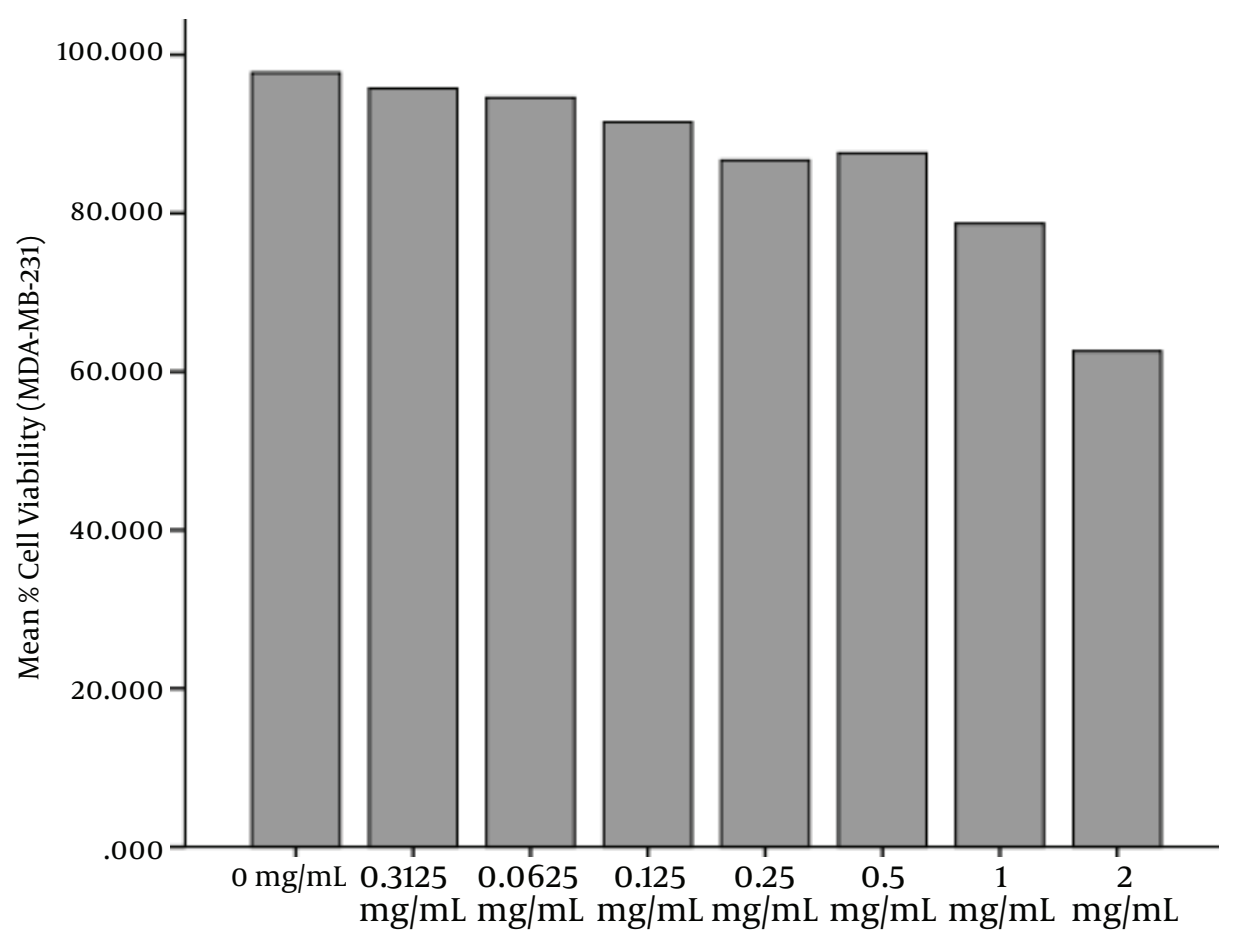

Extract Concentration

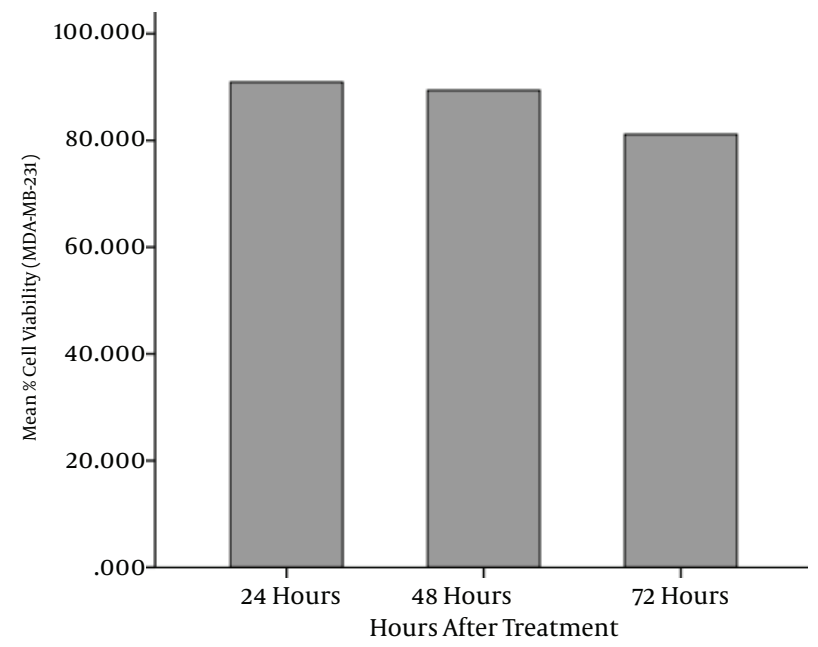

Figure 3. MDA-MB-231 Cell Viability With Respect to Hours of Incubation After Treatment With Watercress Extract 

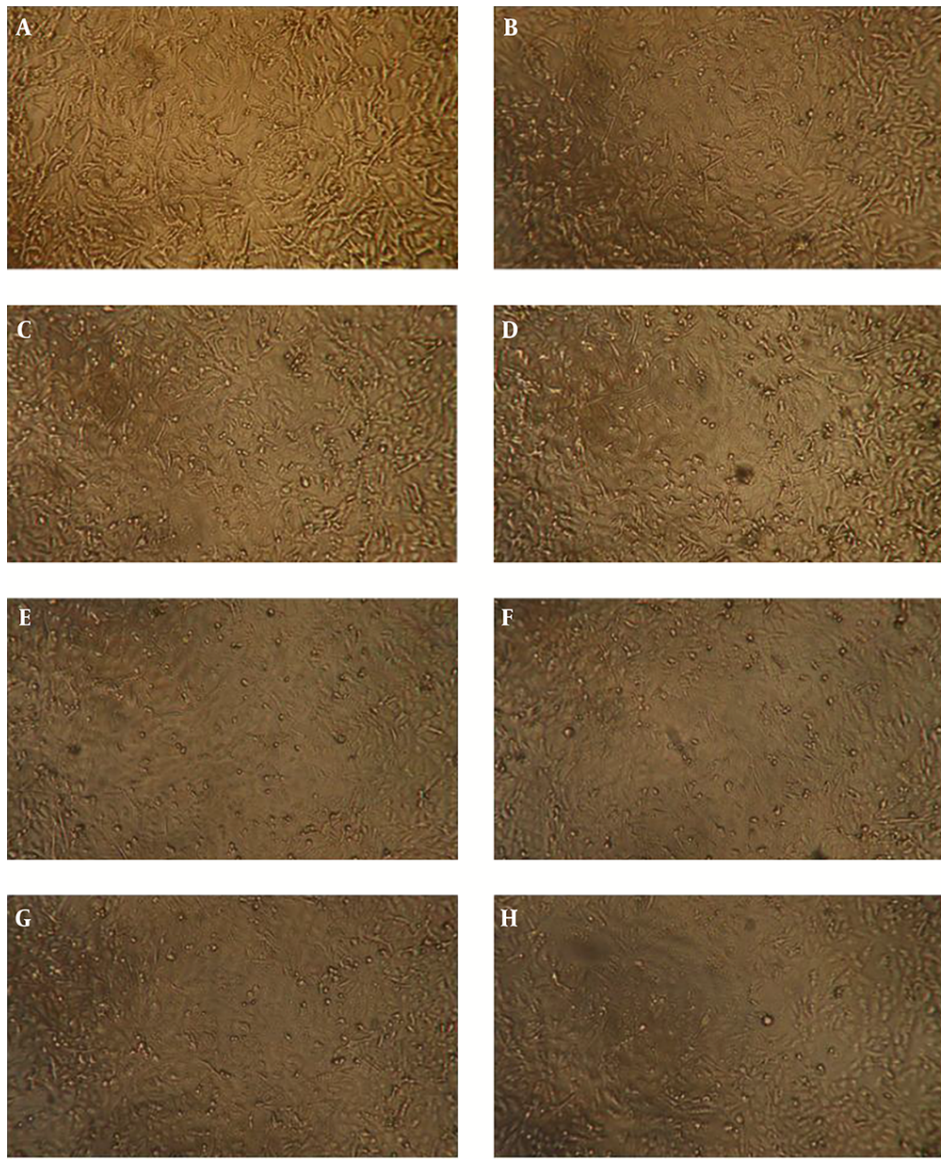

Figure 4. MDA-MB-231 Cells After 72 hours of Incubation Treated With Concentrations of: a) $0 \mathrm{mg} / \mathrm{mL}$ (control group), b) $0.03125 \mathrm{mg} / \mathrm{mL}, \mathrm{c}$ ) $0.0625 \mathrm{mg} / \mathrm{mL}, \mathrm{d}$ ) $0.125 \mathrm{mg} / \mathrm{mL}, \mathrm{e}$ ) $0.250 \mathrm{mg} / \mathrm{mL}, \mathrm{f}) 0.5 \mathrm{mg} / \mathrm{mL}, \mathrm{g}) 1 \mathrm{mg} / \mathrm{mL}$ and h) $2 \mathrm{mg} / \mathrm{mL}$

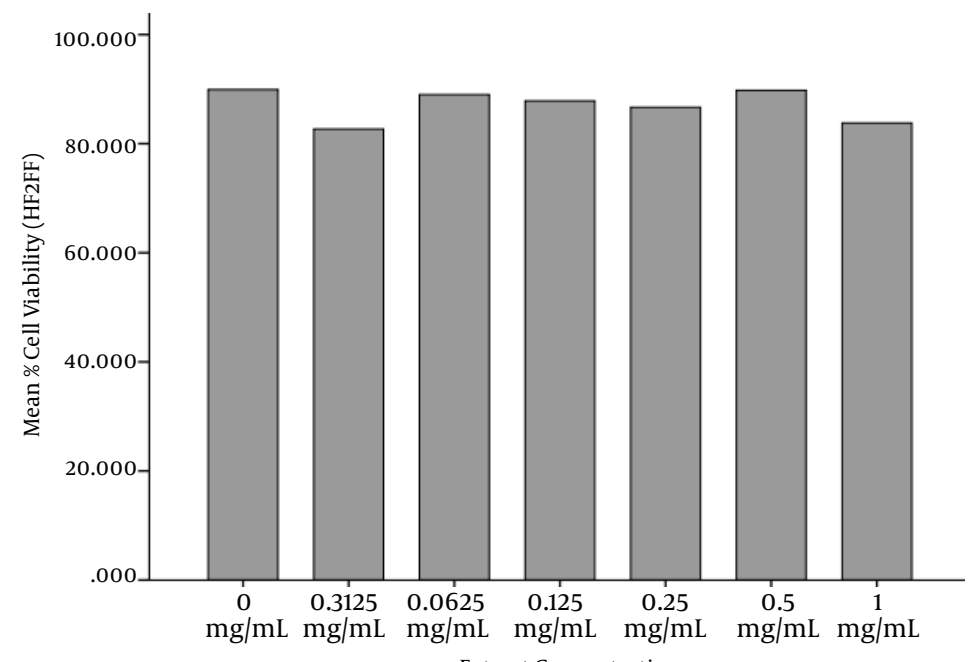

Extract Concentration 


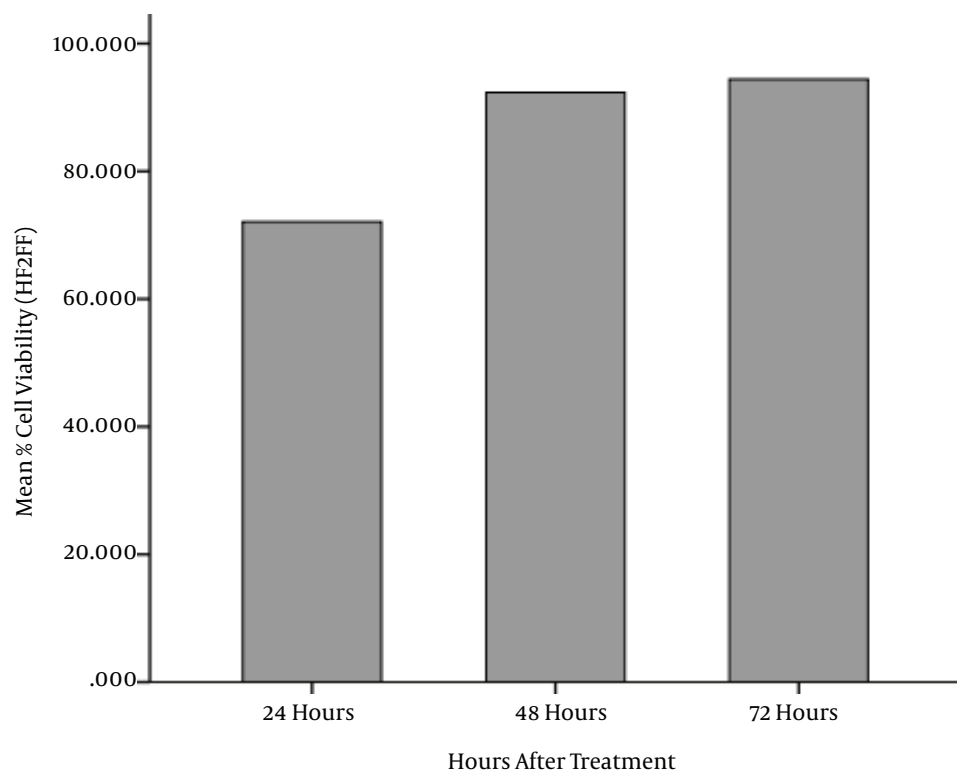

Figure 6. HF2FF Cell Viability With Respect to Hours of Incubation After Treatment With Watercress Extract
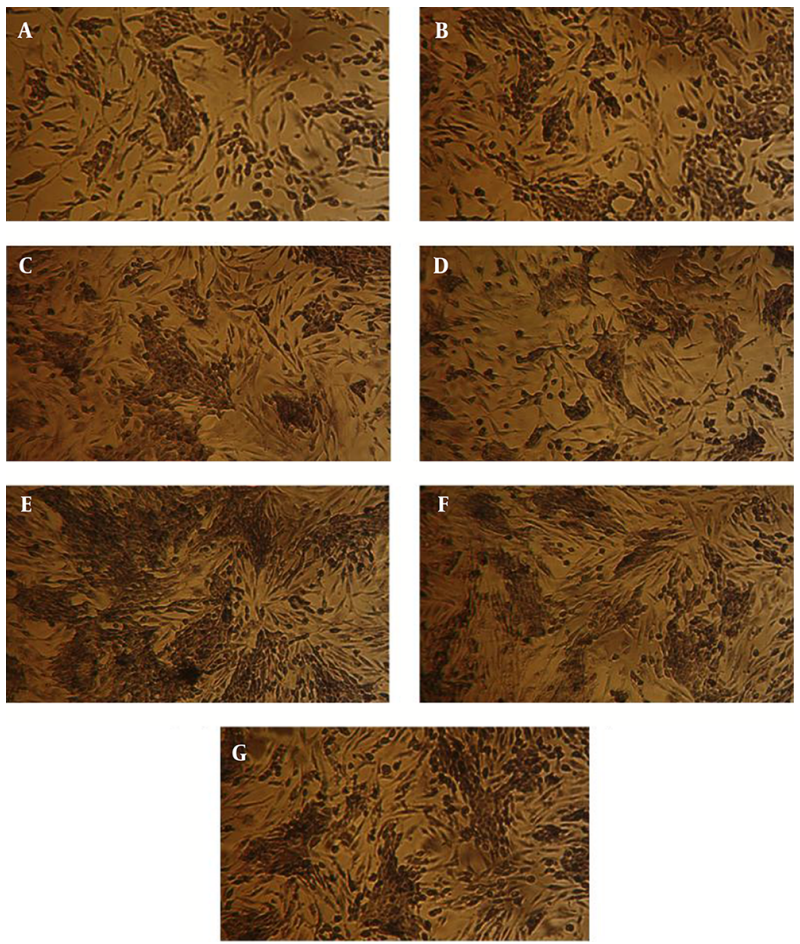

Figure 7. HF2FF Cells After 72 Hours of Incubation Treated With Concentrations of: a) $0 \mathrm{mg} / \mathrm{mL}$ (Control Group), b) $0.03125 \mathrm{mg} / \mathrm{mL}$, c) $0.0625 \mathrm{mg} / \mathrm{mL}$, d) $0.125 \mathrm{mg} / \mathrm{mL}$, e) 0.250 $\mathrm{mg} / \mathrm{mL}$, f) $0.5 \mathrm{mg} / \mathrm{mL}$ and g) $1 \mathrm{mg} / \mathrm{mL}$

and cervical cancer, radiotherapy can make genetic damage on normal cells, and surgery may impose mental syn- 
drome after Mastectomy. Therefore, the need to an effective method with less side effects is really serious and must be considered by researchers.

Since a good drug is a drug having low and continuous impact on cancer cells and it has the least effect on normal cells, we can classify the watercress in the group of appropriate cancer prevention agents which have the least side effect on normal cells. The cancer inhibitory effects of watercress observed in this study may contribute to the suppression of carcinogenesis by diets rich in cruciferous vegetables (e.g. watercress) which are safe, low cost and simple human chemopreventives.

\section{Footnote}

Authors' Contribution: Neda Fallah designed the study, analyzed the data and wrote the article. Soheila Ebrahimi guided this article. All authors read and approved the final manuscript.

\section{References}

1. American Cancer Society . What are the key statistics about breast cancer? 2015. Available from: http://www.cancer.org/cancer/ breastcancer/detailedguide/breast-cancer-key-statistics.

2. Kolahdoozan S, Sadjadi A, Radmard AR, Khademi H. Five common cancers in Iran. Arch Iran Med. 2010;13(2):143-6.

3. Hatefnia E, Niknami S, Bazargan M, Mahmoodi M, Lamyianm M, Alavi N. Correlates of mammography utilization among working Muslim Iranian women. Health Care Women Int. 2010;31(6):499-514. doi: 10.1080/07399331003725507. [PubMed: 20461601].

4. Andersen C, Adamsen L, Moeller T, Midtgaard J, Quist M, Tveteraas A, et al. The effect of a multidimensional exercise programme on symptoms and side-effects in cancer patients undergoing chemotherapythe use of semi-structured diaries. EurJ Oncol Nurs. 2006;10(4):247-62. doi:10.1016/j.ejon.2005.12.007. [PubMed:16476570].

5. Wolff AC. PG 12.04 Long term side effects of adjuvant chemotherapy in patients with early breast cancer. Breast. 2015;24(1):23-4.
6. Zelefsky MJ, Housman DM, Pei X, Alicikus Z, Magsanoc JM, Dauer LT, et al. Incidence of secondary cancer development after high-dose intensity-modulated radiotherapy and image-guided brachytherapy for the treatment of localized prostate cancer. Int J Radiat Oncol Biol Phys. 2012;83(3):953-9. doi: 10.1016/j.ijrobp.2011.08.034. [PubMed: 22172904].

7. Roszak A, Warenczak-Florczak Z, Bratos K, Milecki P. Incidence of radiation toxicity in cervical cancer and endometrial cancer patients treated with radiotherapy alone versus adjuvant radiotherapy. Rep Pract Oncol Radiother. 2012;17(6):332-8. doi: 10.1016/j.rpor.2012.07.005. [PubMed: 24377035].

8. Dyba M, Wang A, Noone AM, Goerlitz D, Shields P, Zheng YL, et al. Metabolism of isothiocyanates in individuals with positive and null GSTT1 and M1 genotypes after drinking watercress juice. Clin Nutr. 2010;29(6):813-8. doi: 10.1016/j.clnu.2010.06.010. [PubMed: 20656381].

9. The Columbia Encyclopedia . Watercress facts, information, pictures 2015. Available from: http://www.encyclopedia.com/topic/ watercress.aspx.

10. United States Department of Agriculture . Agricultural research service. USDA National Nutrient Database for Standard Reference 2015. Available from: http://www.ars.usda.gov/Services/docs.htm?docid= 8964.

11. Syed Alwi SS, Cavell BE, Telang U, Morris ME, Parry BM, Packham G. In vivo modulation of $4 \mathrm{E}$ binding protein 1 (4E-BP1) phosphorylation by watercress: a pilot study. Br J Nutr. 2010;104(9):1288-96. doi: 10.1017/S0007114510002217. [PubMed: 20546646].

12. Rose P, Huang Q, Ong CN, Whiteman M. Broccoli and watercress suppress matrix metalloproteinase-9 activity and invasiveness of human MDA-MB-231 breast cancer cells. Toxicol Appl Pharmacol. 2005;209(2):105-13. doi: 10.1016/j.taap.2005.04.010. [PubMed: 15953625].

13. Yuan P, Chen BA, Liu DL. Anticancer mechanisms and researches of isothiocyanates. Chin J Nat Med. 2008;6(5):325-2.

14. Wang X, Govind S, Sajankila SP, Mi L, Roy R, Chung FL. Phenethyl isothiocyanate sensitizes human cervical cancer cells to apoptosis induced by cisplatin. Mol Nutr Food Res. 2011;55(10):1572-81. doi: 10.1002/mnfr.201000560. [PubMed: 21595016].

15. Keramati K, Mehranpoor M, Babakhani A. Effect of flunixin on ovarian cancer induced by DMBA in female wistar rats. Persian J Knowledge Health. 2012;7(1):44-9.

16. Hansen MB, Nielsen SE, Berg K. Re-examination and further development of a precise and rapid dye method for measuring cell growth/cell kill. J Immunol Methods. 1989;119(2):203-10. [PubMed: 2470825].

17. Riss TL, Moravec RA, Niles AL. Cell viability assays. National Center for Advancing Translational Sciences 2015. 